trees not showing them, to a range of possible indicator varieties and species. In the course of this work an appropriate range of standard indicator hosts for each virus group is being determined, and improved grafting techniques for obtaining quick test results have been devised and put into general use.

The problem as it concerns the scion and rootstor $k$ of tree fruits is a dual one, the effect of a rootstock infection being a permanent and growing source of tree infection unless it is eliminated, and that of scion-tree infection mors localized and more likely to be eliminated in the normal course of propagation. Also, a combination of stock and scion each infectod with different viruses may synthesize complex diseases, which may be disseminated if stocks on which grafts have failed are regrafted or returned to stoolbeds for continued propagation. In this brief survey of present early trends and discoveries, the scion and stock problems will therefore be dealt with separately.

Virus diseases in scion varieties.

Apples. Apple mosaic virus was found to exist in several strains of different virulence, and strains causing extensive leaf chlorosis and defoliation of a variety will probably affect its yield. But varieties differ greatly in their sensitivity to these strains, so that a strain can only be defined as severe in relation to a specified variety, and hence the danger of 'topgrafting' a sensitive on to a tolerant variety. The effects of the rubbery wood virus on a wide range of varieties, additional to the sensitive variety Lord Lambourne, is being determined, following the discovery of the wide distribution of these diseases through infected stoolbeds (see below).

Pear. Besides stony-pit, two diseases of the veinbanding and leaf-flecking type have been identified and appear to have a stunting effect on quinceseedling indicator plants. The possible importance of these viruses in stock-scion incompatibility phenomena is being studied.

Cherry. Four groups of symptoms have been identified and are being studied by graft transmission to a range of species and varieties : rasp leaf, tatter leaf, rosette and rusty mottle. The three latter have reduced the vigour of a clonal rootstock $(F 12 / 1)$ by about 20 per cent (girth and height) in two years. Rasp leaf is a more severe disease in its effects, not on $F^{1} 12 / 1$, but on most commercial varieties. As its occurrence is comparatively rare, total loss from rasp leaf is probably much less than that from more commonly distributed viruses such as rusty mottle.

Plum. 'The common vein-banding or line pattern leaf symptoms in plum are probably caused by several viruses. In general, plums are more tolerant to virus diseases than are cherries, and viruses from almost symptomless plums have been found to cause severe leaf-necrosis on cherry. Two recently discovered symptom types on plum, a leaf roll and a bark splitting, are both potentially serious diseases on certain varieties, particularly the gages.

Virus diseases in root-stocks.

Vegetative races of root-stocks hitherto developed at East Malling without reference to the ingress and subsequent dissemination of viruses are being extensively surveyed, with the following results to date.

Apple root-stocks. Some stools of $M I$ and $M I X$ at East Malling were found in preliminary tests to be infected, without symptoms, with rubbery wood virus. Other varieties of the Malling series from commercial sources were also found to be extensively infected with this virus, and arrangements are in hand $t$, continue the survey on a wider basis with the aim of re-selecting and developing virus-free clones where necessary.

Quince root-stocks (for pear) are under investigation and some infection has been identified.

Plum root-stocks are mainly symptomless carriers, and preliminary tests have detected a widely distributed virus in common plum and Marianna stock. There is some, but probably less, infection in the Myrobalan $B$ and Brompton stocks.

Cherry root-stocks. Some clones of Mazzard selections have been found to be infected with ringspot; but the most important selection, $F 12 / 1$, is mainly free from virus. The latter stock, unlike those of plum, commonly shows symptoms when infected, and beds can then be 'rouged' at sight; $F 12 / 1$ is, in fact, used as an indicator-host in our studies of stone fruit viruses.

Selection of healthy propagating stock and indexing of trials. The first step towards the control of these diseases of tree fruits is their elimination from the material used for propagation. This involves not only the re-selection and raising of virus-free rootstocks, but also the selection and distribution of virus-free scion material. This work has already begun, and a survey, by graft-indexing, of virus diseases in existing trials at this Research Station is being undertaken. Plans are also contemplated for investigating the natural vectors of these diseases.

' Posnette, A. F., Nature, 189, 837 (1952).

\section{EDUCATION AND TRAINING OF METALLURGISTS}

'HE presidential address by Prof. Hugh O'Neill to the Institution of Metallurgists given on June 26 was concerned, first, with the education of metallurgists and, secondly, the maintenance of a high standard of professional conduct.

Whether the founders of the Institution intended it or not, it is a company showing a strong resemblance to the early craft guilds. The three grades of membership, like the corresponding degrees at the universities, were grades through which every common man could pass. They were not social classes; they were degrees and not castes. Professional qualifications were required in many countries during the Middle Ages before a man could practise as a metallurgist. Thus in 1438 Charles VI of France decided that nobody in any town, village or hamlet in Dauphiné could make iron or steel if his competence had not been officially recognized. The old worker, and those who wished to become workers, were examined by an official assisted by two or three experts, who judged their aptitudes and experience. Just as in the days of the Guilds when the apprentices were not only taught the trade, but also received some general education, so is the Institution interested in the training of its members. It is recorded that a goldsmith's apprentice in 1494 agreed to serve ten years instead of nine, provided that his master would keep him one year at a writing school. Among the goldsmiths, fines were inflicted for failing to have the apprentices taught reading and writing. These craft guilds were friendly 
societies, concerned with the welfare of the whole man. They had their religious observances and their festivitios.

There is still an element of dissatisfaction, which university teachers themselves share, with the training at present given to many students of metallurgy. Someone wrote to me to say that after interviewing several hundred science graduates he concluded that in all the British universities insufficient attention is directed to the underlying science and philosophy of the subject. He believed that teaching in the history and philosophy of science, plus an account of scientific method, with further philosophical teaching on the nature of truth, are essential ingredients in the training of any man of science who wishes to describe himself as well educated. A further criticism of current training is that: "The educated scientist knows that his science is derived only from a part of experience, and that it does not, and cannot, concern itself with the most important aspects of human life. The universities are to blame. They were instituted to give an education, but to their science students they give little more than technical training. They are, in general, expending far less effort in making wise men and good citizens, than in turning out good employees for commerce and industry. This can be remedied in part at least by insistence that the study of the nature of science should be a necessary part of the training of scientists, and should enter into every final examination".

Fxactly one hundred years ago there was penned in Birmingham a famous discourse entitled "Knowledge Viewed in Relation to Professional Skill", John Henry Newman was outlining his ideas about universities, and advocating "liberal education" combined with specialist studies as a definite means of "cultivating the intellect". According to Newman "... the man who has learned to think and to reason and to compare and to discriminate and to analyse, who has refined his taste and formed his judgement, and sharpened his mental vision, will not indeed at once be . . a an engineer, or a chemist, or a geologist . . . but he will be placed in that state of intellect in which he can take up any one of the sciences... with an ease, a grace, a versatility, and a success, to which another is a stranger".

Some writers would claim that science itself is an adequate basis for the life of a university or nation, especially because of its sociological developments. I must, however, mention a hilarious essay written in this connexion by a serious scientist, which ends thus : "We can, and should, laugh out loud at scientists and this will be the very best way to prevent them from regulating us, or averaging us, or conditioning us to synthetic happiness. For what are they doing? The most laughable thing in the world. They are all crowding round and bowing low before a Sacred Cow". Without being cynical about science we need not become worshippers. In the last century it avoided metaphysics, whereas to-day we have Schrödinger stating: "I consider science an integrating part of our endeavour to answer the one great philosophical question which embraces all others, the one that Plotinus expressed by his brief- who are we?, and more than that; I consider this not only one of the tasks, but the task of science, the only one that really counts". Sir Walter Moberly, in discussing how the universities should attempt to implant a wide culture, has recommended a limit to religious neutrality, and an active probing of the common values which are held by most men.

It is generally agreed that intense specialization at the undergraduate stage should be avoided. In the words of Prof. Woodward, no one should receive an honours degree without showing "that minimum of general understanding which differentiates education from technical skill". Fortunately in Britain, with its independent universities, we have largely avoided what an American professor has sadly described as the assembly-line technique: "The part affixed in this industrial process is the course. . . The course is a neat unit of knowledge, complete in itsolf, duly fastened to the student's mind, inspected, passedforgotten. Once it is on, it is on, and we do not have to worry about it any more. When a student has had all the courses bolted on, we look him over to see that nothing has been forgotten, we add up the credits that the courses are worth, and if what we find agrees with the specifications ... we give him a degree which signifies that he has a college education". The dilemma arises, however, in connexion with the distribution of time for all the work to be done. Some will take the view that the life of Britain depends upon the discovery, development and export of high-quality specialities. For this first-class men of science are required. It still seems to me, however, that we should maintain the broad basis for the bachelor's degree, and intensify specialization in postgraduate work.

The question may be asked : is there such a thing as 'cultural metallurgy'? Prof. John Read recently developed an earlier opinion that "Chemistry itself may become a cultural and humanistic instrument of high value". To that may be added the following statement of Lord Waverley (formerly Sir John Anderson) in his 1951 May Lecture to the Institute of Metals : "I wish it could be universally recognized that scientific studies no less than the humanities have a cultural value, and that applied science is not inferior academically to pure science". For metallurgy to have any humanistic qualities it would probably have to include the history of the subject, and this indeed was the main point of Read's lecture.

How are we to set up and maintain a high standard of professional conduct? This is a moral matter, and increasingly one hears the expression that there is no morality or culture without religion. If we pursue the analogy with the craft guilds mentioned earlier, we find a general understanding that guild conduct should be based on definite religious principles. There would, of course, be hostility from some quarters at attempts to bring Christian principles directly into the sphere of professional conduct, but one cannot help noticing that at a meeting of the representatives of British, French, German and Italian steel industries at Caux, the great need for absolute moral standards in industry was emphasized. There is, however, another direction in which metallurgists in high positions may have to take a definite line regarding their professional conduct. In the development of primitive regions metallurgists should use their influence to see that the conduct of the enterprise corresponds with the natural rights of mankind.

I would conclude by a quotation from a letter signed by "A Professor", presumably American, on "What do we in the Universities believe ?" :

"... Underneath our devotion to the fictitious reality, which the physicist at the Einstein level has 
destroyed, lies sleeping a faith in the existence of a moral universe; in the existence of a natural law which gives to man certain inalienable rights ; in a Divine Creator of which we are each a tiny spark. . . . But we are scarcely aware of these foundations far beneath our everyday lives. ... Only when thanmade laws challenge man's inalienable rights do we realise whence comes our belief in these rights".

\section{F. C. THOMPSON}

\section{OBITUARIES}

\section{Sir Lindsay Scott, K.C.B.}

Sir Lindsay Scotr, who died on June 17, was an outstanding example of the finest tradition of the amateur in the field of humane studies. A Civil servant fulfilling the exacting duties of a senior official in a war department in peace-time and during hostilities, he nevertheless made a notable place for himself in British archæological research by his resolute determination to match his work against nothing less than that of the highest professional standards in the field or in the museum and library. With a naturally vigorous and original mind, sharpened and disciplined by academic training, he brought to his studies of British prehistory a freshness and directness of approach which was always well ballasted by precise and detailed documentation, and illuminated by direct personal experience. $\mathrm{He}$ was, in the eighteenth-century sense of the word, a 'curious' person: his reading w'as wide and unconventional, and in particular his knowledge of the byways of English literature from its beginnings to the nineteenth century was as varied and unexpected as it was entertaining to his friends, and to this he added a robust and competent command of the practical skills of the countryman and the sailor.

His work was specifically directed to problems of Scottish prehistory, and his main excavations were carried out in the Outer Isles, where perhaps he felt most at home; but these local studies were invariably made within the framework of European prehistory as a whole, and he carried on an amused, but none the less sincere, campaign against provincialism and isolation in such researches. Always provocative (sometimes deliberately and healthily so), his contributions to the archæology of Scotland, both in the form of excavations admirably carried out and meticulously recorded, and in subsequent comment upon the wider aspects of the problems involved, will remain as a permanent memorial to his immense energy and to his devotion to exacting standards of scholarship. These, and his work on the Council for British Archæology and as president of the Prehistoric Society, have ensured him a place among the more powerful forces in the post-war development of prehistoric studies in Great Britain.

Stuart Piggott

\section{Mr. F. W. H. Migeod}

Frederick William Hugh Migeod was born on August 9, 1872, in Chislehurst, Kent, and went to school in Folkestone. When he was seventeen he joined the pay department of the Royal Navy, and although he had a love for the sea and an interest in those who serve in ships, he was not destined to devote his life to it. After nine years he left the Navy and in 1900 he joined the Colonial Civil Service.
All his subsequent service was in Africa, and most of it in West Africa, though he made several important and hazardous journeys across the continent. His curiosity concerning the languages and customs of the various races was insatiable, and his researches resulted in five volumes on languages and four quite considerable travel books. Wherever he went he observed closely, and he amassed a store of natural history knowledge that he used in later writings.

In 1925, when the British Museum East Africa Expedition was left leaderless through the death of W. E. Cutler, Migeod volunteered from England for the post, and intermittently for the next four years or so he acted as general overseer of the operations. On the whole, he had little success in this, and it is paradoxical that through the nature of the work he came into the public eye much more than he ever did through his able and successful studies in folk-lore and language. It is only fair to say that Migeod in these later years did not claim much for his East African adventure.

Migeod's years of retirement in Worthing were characteristically busy. He wrote a book, "Earliest Man", and another volume, "Aspects of Evolution", which displayed a rather fundamentalist point of view; but also revealed a surprising range of observation and width of knowledge of the literature. $\mathrm{He}$ also wrote a survey of Worthing.

Migeod was a Fellow of the Royal Geographical and the Royal Anthropological Societies for many years. $\mathrm{He}$ had been president of the Worthing Archæological Society in 1927 and he was re-elected in 1938. He also entered local government as a town councillor, eventually becoming an alderman both of Worthing and of the County of Sussex. He was for many years chairman of the local sea-cadet force.

His manner of speech and bearing sometimes gave an impression of arrogance; but in fact he was a kindly and friendly man and an admirable host. Fortune seldom shone on him. His married life was happy but brief, and his wife died many years ago. For the last year or two he had been ill and much alone, and the end came on July 8.

\section{W. E. SWINTON}

\section{Prof. Tadeusz Estreicher}

Prof. TAdeusz Estreicher (Thaddaeus EstreicherRozbierski), a member of an ancient and cultured Polish family and one of Poland's most distinguished and versatile men of science, died in Cracow on April 8. Son of Karol Estreicher, bibliographer and director of the University library, he was born in Cracow on December 19, 1871. He enrolled as a student in the famous Jagiellonian University of Cracow, founded in 1364, where he became a favourite pupil of Karol Olszewski, the celebrated chemist. In 1894, at the request of Sir William Ramsay, Olszewski had begun experiments on the liquefaction of argon; Estreicher participated in this work with distinction, and graduated Ph.D. in 1897. After working in the laboratories of van 't Hoff (Berlin), Ostwald (Leipzig) and Ramsay (London), he returned to Cracow as a Docent in inorganic and analytical chemistry; at the same time he helped to modernize Olszewski's laboratory. A further year's work with Abegg (Breslau) was followed by his appointment, in 1906, as professor of inorganic and analytical chemistry at the University of Fribourg, in Switzerland, a chair which he 